\title{
How patent law reform can improve affordability and accessibility of medicines in South Africa: Four medicine case studies
}

C Tomlinson, ${ }^{1}$ MA (Public Health); C Waterhouse, ${ }^{2}$ MA (Human Rights Law); Y Q Hu, ${ }^{2}$ PhD Law; S Meyer, ${ }^{3}$ MSocSci (SW); H Moyo, ${ }^{3}$ BPharm Hons

${ }^{1}$ Fix the Patent Laws, Johannesburg, South Africa

${ }^{2}$ Doctors Without Borders, Johannesburg, South Africa

${ }^{3}$ Cancer Alliance, Cape Town, South Africa

Corresponding author: C Tomlinson (crtomlinson@gmail.com)

South Africa (SA) is in the process of amending its patent laws. Since its 2011 inception, Fix the Patent Laws, a coalition of 40 patient groups, has advocated for reform of SA's patent laws to improve affordability of medicines in the country. Building on two draft policies (2013, 2017) and a consultative framework (2016) for reform of SA's patent laws, Cabinet approved phase 1 of the Intellectual Property Policy of the Republic of South Africa on 23 May 2018. Fix the Patent Laws welcomed the policy, but highlighted concerns regarding the absence of important technical details, as well as the urgent need for government to develop bills, regulations and guidelines to provide technical detail and to codify and implement patent law reform in the country. In this article, we explore how reforms proposed in SA's new intellectual property policy could improve access to medicine through four medicine case studies.

S Afr Med J 2019;109(6):387-391. DOI:10.7196/SAMJ.2019.v109i6.14001

Fix the Patent Laws, a coalition of 40 patient groups, was launched in 2011 by the Treatment Action Campaign, SECTION27 and Doctors Without Borders to advocate for reform of South Africa (SA)'s patent laws to fully adopt safeguards provided under the Agreement on Trade-Related Aspects of Intellectual Property Rights (TRIPS). As a member of the World Trade Organization (WTO) and a middleincome country, SA is required by TRIPS to provide 20 years of patent protection on novel innovations. While TRIPS sets out standards of protection that WTO members are required to provide, it also contains safeguards (also known as flexibilities) that countries can adopt in national laws and implement in their countries to protect health.

The right of countries to adopt health safeguards in their national patent laws and the importance of their use in promoting and securing access to medicines have been reaffirmed in many international fora. In 2001, members of the WTO adopted the Doha Declaration on the TRIPS Agreement and Public Health (Doha Declaration), stating that 'the [TRIPS] Agreement can and should be interpreted and implemented in a manner supportive of WTO Members' right to protect public health and, in particular, to promote access to medicines for all. ${ }^{[1]}$ The World Health Organization has passed several resolutions affirming the rights of countries to use TRIPS safeguards to improve medicine access. ${ }^{[2]}$ And in 2016, the United Nations High-Level Panel on Access to Medicines stated that 'WTO members should make full use of [TRIPS] flexibilities as confirmed by the Doha Declaration to promote access to health technologies when necessary. ${ }^{\text {[3] }}$

Despite the repeated assertion in international fora regarding the importance of including health safeguards in patent laws and the right of countries to do so, few countries have fully adopted them into their national laws. TRIPS-compliant middle-income countries in particular have faced significant pressure against the adoption and use of these safeguards. Pressure tactics have included legal challenges by multinational pharmaceutical companies, as well as political and trade pressure by wealthy countries seeking to bolster pharmaceutical sales and profits in middle-income country markets. ${ }^{[3]}$

In this article we explore how the lack of health safeguards in SA's patent laws negatively impact on medicine access and discuss the need for urgent reform of the country's patent laws and procedures as committed to in the recent intellectual property (IP) policy. Health safeguards considered in the article include patentability criteria, substantive examination and opposition procedures, and compulsory licensing.

Patent data provided in this article were sourced from the Companies and Intellectual Property Commission, the World Intellectual Property Organisation and Medspal's online patent databases, as well as patent data and analyses supplied by I-MAK and the Medicines Patent Pool. Pricing data were sourced from the Medicines Price Registry (for SA) and 1mg.com (for India). India was selected as a pricing comparator country because historically it has progressively adopted TRIPS health safeguards into its national laws, and because it is a leading global supplier of generic medicines. ${ }^{[4]}$

All patent and pricing data used in this article were extracted between May and July 2018 and can be reviewed in Annexure 1 (http://bit.ly/2SNu9pN).

\section{Patentabillity criteria}

While primary patents are generally granted on a medicine's base compound or biological molecule, secondary patents can be granted on a range of claims including derivatives, formulations, dosages, combinations, uses and production processes. The strategy of extending patent monopoly lengths through secondary patent claims is commonly known as 'patent evergreening'.

Studies have demonstrated rising rates of secondary patenting of medicines following TRIPS adoption in $1995 .{ }^{[5-7]}$ According to 
a pharmaceutical sector inquiry by the European Commission, secondary patenting of medicines skyrocketed in the 1990s as part of a 'toolbox' of strategies employed by pharmaceutical companies to extend their commercial monopolies beyond 20 years. ${ }^{[5]}$

The UN High-Level Panel on Access to Medicines recently stated that 'secondary patents can create legal uncertainty around the patent status of a health technology, which in turn discourages entities from procuring generic versions of products for fear of patent infringement. ${ }^{[3]}$

While TRIPS requires that countries provide 20 years of patent protection on products and processes that are 'new, involve an inventive step and are capable of industrial application', it provides the leeway for countries to define what is meant by these three terms ${ }^{[8]}$ in establishing their national patentability criteria. Patentability criteria are the requirements that applicants must meet to be eligible for patent protection. To date, a number of countries, including India ${ }^{[9]}$ and Argentina ${ }^{[10]}$ have adopted strong patentability criteria to combat patent evergreening.

SA's recently adopted IP policy stated that 'patentability criteria will be developed in order to promote genuine innovation through the patent system in South Africa'; ${ }^{[11]}$ however, it does not provide guidance on the patentability of common secondary applications. Currently SA does not have explicit criteria for the granting of patents, which creates significant legal ambiguity regarding the patentability of weak secondary claims. The IP policy, however, provides a valuable opportunity to clarify patentability criteria to prevent patent evergreening in the upcoming process of policy implementation and law reform.

\section{Substantive examination and opposition procedures}

TRIPS further provides for countries and jurisdictions to adopt and implement substantive examination procedures to ensure that patentability criteria are met prior to the granting of patents. Currently, patents are granted in SA via a 'depository system'. Under such a system, patents are granted on all applications for which forms are correctly filed and fees are paid without substantive examination of the application's merits. ${ }^{[12]}$ As a result, SA commonly grants many patents that are rejected or withdrawn in other jurisdictions where substantive examination of patent applications is conducted.

A review of the outcome of matching pharmaceutical patent applications filed in different jurisdictions found that SA is an outlier with regard to its high patent grant rate. Sampat and Shadlen ${ }^{[13]}$ reported that on matching patent applications filed between 2000 and 2002 , SA granted $93 \%$ of patents applied for, v. $61 \%$ in the USA, $51 \%$ in Europe and 29\% in Japan. They also noted that 'since South Africa does not examine applications, the only applications not granted there are those withdrawn during the examination process due to failure to pay issue fees, and (a very small number) applications still pending. ${ }^{[13]}$

A further shortcoming of SA's current laws and procedures for granting patents is the lack of patent opposition procedures. Patent opposition procedures are commonly used by patents offices (including in the USA, ${ }^{[14]}$ India (Patents Act 39 of 1970, ${ }^{[9]}$ Section 25), Argentina, ${ }^{[15]}$ South Korea ${ }^{[16]}$ and the $\mathrm{EU}^{[17]}$ ) to allow third parties to challenge the validity of patent applications prior to and/or after their granting. ${ }^{[18]}$

Currently the only way to oppose a patent in SA is by undertaking litigation - generally a lengthy and prohibitively expensive process. ${ }^{[19]}$ Yet, research by Fix the Patent Laws and the Cancer Alliance shows that patent litigation is rare in SA in comparison with countries with larger pharmaceutical markets. ${ }^{[20,21]}$ Further, when litigation does occur, SA's courts typically rule conservatively, applying a low bar for novelty and inventiveness and erring in favour of upholding the patent holder's protections over public interest. ${ }^{[22-24]}$

Importantly, the recent IP policy approved by Cabinet called for the adoption of substantive examination and opposition procedures starting from introducing third-party observations and post-grant administrative reviews. ${ }^{[11]}$ However, the policy did not provide clear time frames for implementing these procedures and noted that a third-party observation system may be implemented as an interim measure prior to the establishment of opposition procedures. A third-party observation would allow third parties to provide information to the patents office assessing the patentability of applications and validity of patent claims against the criteria, but would not trigger formal procedures involving the third party. While the interim consideration offers a positive opportunity to start establishing the mechanism of opposition, a clearer timeline of implementation is important to prevent further delays in reforming practices.

\section{Compulsory licensing}

Arguably, one of the most important health safeguards provided for under TRIPS is the ability of WTO members to grant compulsory licensing without the consent of the patent holders, on the grounds defined by national laws, in order to use an invention or allow its use by a third party. ${ }^{[25]}$ Unlike voluntary licences, which are granted by the patent holder, a compulsory licence is a licence granted by a competent public authority or court that allows for the manufacture, marketing, import and export of generic products with royalty payments to the patent holder.

TRIPS provides for the granting of compulsory licences to protect health, and the Doha Declaration ${ }^{[1]}$ clearly affirms the freedom of countries to determine the grounds for issuing compulsory licences (paragraph 5(b)). The importance of utilising this flexibility was recently reaffirmed by the UN High-Level Panel on Access to Medicines, which stated that ' $[\mathrm{c}$ ] ompulsory licenses are an important policy tool for government authorities to promote access to health technologies. ${ }^{[3]}$

To date, SA has not utilised this important flexibility owing to a combination of unworkable domestic legal procedures for issuing compulsory licences ${ }^{[26]}$ and international pressure against their use. ${ }^{[27]}$ While SA has never issued a compulsory licence on a pharmaceutical product, this flexibility has been used repeatedly in other jurisdictions to facilitate generic medicine access. ${ }^{[28]}$

Importantly, SA's recently adopted IP policy committed to the adoption of 'more effective and efficient' mechanisms for granting compulsory licences in SA to facilitate the use of this flexibility to protect public health.

\section{Medicine case studies}

We provide four medicine case studies, on lenalidomide, entecavir, erlotinib and sorafenib, to illustrate how concrete reform of SA's patent law can facilitate greater medicine access and equity between the public and private health sectors. The lenalidomide, entecavir and erlotinib case studies highlight how the adoption of strong patentability criteria, as well as substantive examination and opposition procedures, would reduce the granting of secondary patents and allow for earlier access to more affordable generic products. The sorafenib case study highlights how compulsory licensing can be applied when granted patents inhibit access owing to excessive pricing of patented products or other challenges. 
The case studies are drawn from two reports published by Fix the Patent Laws, Doctors Without Borders and the Cancer Alliance that provide patient stories and medicine examples highlighting the negative impact of SA's patent laws on medicine access and patients' lives. ${ }^{[29,30]}$ Patent data provided in this article have been updated with additional patent data sourced from Unitaid's Medspal database and provided by I-MAK following publication of the earlier reports.

\section{Lenalidomide}

Lenalidomide is indicated for the treatment of multiple myeloma and some types of myelodysplastic syndromes. Base product patents were filed on lenalidomide with the international Patent Cooperation Treaty in 1997 and 1998 (PCT/US1997/013375, PCT/ US1998/010886). Neither of the base patents was filed in SA; however, 32 secondary patents related to lenalidomide filed by Celgene were subsequently granted in SA. The majority of secondary patents granted on lenalidomide were granted on methods of use, including on unapproved indications that were later abandoned given lack of efficacy data.

In cross-checking patents granted in SA with matching applications sought in other jurisdictions on the World Intellectual Property Organization's Patentscope database, we found that for all patents granted on lenalidomide in SA a matching patent application (or divisional application thereof) was withdrawn or rejected in at least one other jurisdiction (Annexure 1, http://bit.ly/2SNu9pN). In other words, many patents granted in SA were rejected in other jurisdictions following substantive examination, or granted for a smaller scope of protection following rejection of the broader scope of protection initially filed.

For multiple myeloma treatment, lenalidomide is generally taken for 3 weeks (followed by 1 week off treatment), starting at doses of $25 \mathrm{mg}$. In India, where generic lenalidomide is available, a year of generic lenalidomide costs $\sim$ ZAR31 072. Prior to the registration of Celgene's patented lenalidomide in SA in 2016, a number of multiple myeloma patients were able to import generic lenalidomide from India with Section 21 authorisation from the Medicines Control Council (now the South African Health Products Regulatory Authority). However, these authorisations were cancelled following the registration of Celgene's patented product, which is sold in SA at ZAR729 379 annually - 23 times more than the cost of generics in India. With pro bono legal support, the Cancer Alliance has assisted previously treated patients in securing further authorisation from the South African Health Products Regulatory Authority for generic lenalidomide importation. However, new patients in need of lenalidomide must pay exorbitant costs for the patented product or forgo the treatment.

Lenalidomide is not available in SA's public sector. Access to the lower-cost generic products could expand access in both the private and public sectors.

\section{Entecavir}

Entecavir is indicated for the treatment of hepatitis B. The primary patent granted on entecavir in SA expired in 2011, but a secondary patent granted to Bristol-Myers Squibb (BMS) on low-dose formulations of entecavir could inhibit the use of generics until 2021 - an additional 10 years after the primary patent expired. The same secondary patent was challenged by Cipla and Natco in India, resulting in an out-of-court settlement permitting generic manufacture and use. ${ }^{[31]}$

Entecavir is generally taken for life at daily doses of 0.5 to $1 \mathrm{mg}$. Depending on the dosage needed, a year of BMS's patented entecavir in SA costs ZAR33 354 - 66 695. In India, where generics are available, a year of entecavir treatment costs ZAR5 695 - 8759 . Entecavir is not available in SA's public sector unless special permission is granted for its procurement via a hospital pharmaceutical therapeutics committee.

\section{Erlotinib}

Erlotinib is indicated for the treatment of 'locally advanced or metastatic adenocarcinoma of the lung after failure of at least one prior chemotherapy regimen. ${ }^{\text {'[2] }}$ The primary patent granted on erlotinib in SA (1996/02522) expired in 2016. However, three additional secondary patents granted on erlotinib in SA (2002/03130, $2005 / 06339,2013 / 08062$ ) on polymorphs, combinations and methods of use could extend the monopoly on this medicine until 2032 36 years after the initial patent was granted.

A granted secondary patent (ZA 2002/03130) upheld in SA was rejected in India following opposition, allowing for introduction of generics. ${ }^{[33]}$ Subsequent litigation related to this and other patents granted to Roche on erlotinib in India failed to block the use of generics, and was eventually settled out of court. ${ }^{[34,35]}$ Additionally, the corresponding combination patent granted in SA (ZA 2013/08062) was refused in South Korea ${ }^{[36]}$ and withdrawn in Israel ${ }^{[37]}$ and at the European Patents Office. ${ }^{[38]}$

For the treatment of non-small-cell lung cancer, erlotinib is generally taken at daily doses of $150 \mathrm{mg}$ for as long as clinical benefit is provided. At this dose, a year of erlotinib treatment in SA, where only the patented product is available, costs ZAR317 313. Conversely, in India, where generics are already available, a year's treatment at daily doses of $150 \mathrm{mg}$ costs ZAR24 042 .

\section{Sorafenib}

Sorafenib is indicated for the treatment of advanced renal cell carcinoma and advanced inoperable hepatocellular carcinoma. The initial patent on sorafenib (ZA 2001/05751) was granted in SA in 2001. Subsequently, three secondary patents were granted that could extend Bayer's patent monopoly on the medicine until 2026. In comparison, the Indian government issued a compulsory licence on the initial patent in 2012, allowing for the introduction and use of generic products. ${ }^{[39]}$

Sorafenib is generally taken as a long-term treatment for as long as clinical benefit is provided, at a standard dose of $800 \mathrm{mg}$ daily. In India, where generics are available, a year of sorafenib treatment costs ZAR16 531. Conversely, in SA, where only patented products are available, a year's treatment costs ZAR333 $028-20$ times more than the cost of the generic in India.

\section{Discussion}

The medicine examples in this article highlight how the lack of strong patentability criteria, examination and opposition procedures facilitates high prices and unchecked patent evergreening in SA, blocking access to more affordable generic sources for patients in this country. ${ }^{[29]}$ Many patents granted in SA were rejected - or granted on a smaller scope of protection - following examination and/or opposition in other jurisdictions. Secondary patents granted on lenalidomide, entecavir and erlotinib could prevent the use of generic products in SA for more than 10 years after the initial 20 -year period of patent protection has ended.

The impact of patent evergreening can have devastating consequences for patients. None of the four medicines considered in this article is available in the public sector. For all of the medicines reviewed, generic products in India are available at 
fractions (between $5 \%$ and $13 \%$ ) of the costs of patented products in SA (Fig. 1). As $\sim 80 \%$ of people living in SA access care via the public sector, ${ }^{[40]}$ provision in this sector would significantly enhance medicine access in the country.

To curb patent evergreening, SA must urgently adopt strong patentability criteria, combined with substantive examination and opposition procedures to ensure that patentability criteria are upheld. Further, SA should implement efficient compulsory licensing procedures to facilitate licensing when patents impact negatively on health such as when prices prevent medicine provision through the public sector.

Importantly, SA has taken the first step towards reforming the country's patent laws to better promote and protect public health through the recent adoption of phase 1 of a new IP policy. However, the policy lacks important technical details (such as criteria for pharmaceutical patentability) and will require regulatory reforms and/or the development of regulations and guidelines for its implementation. In the meantime, many important medicines such as the case study medicines highlighted in this article remain inaccessible to most people living in the country.

Government must therefore act swiftly to protect the health and lives of its citizens through urgently converting its policy commitments into legislative and procedural reforms to fully employ TRIPS safeguards in SA.

In addition to the full adoption of TRIPS safeguards, government must take measures to improve patent transparency in SA. To date, Fix the Patent Laws has published two reports collectively outlining patent landscapes for 30 medicines in SA. Its efforts to compile patent landscapes revealed the significant complexity of identifying relevant and blocking patents on health technologies due to inadequate transparency requirements of government and efforts by companies to create ambiguity within patent applications and hide data on pending and granted patents.

While it is commendable that SA publishes some patent data on an online searchable database, ${ }^{[41]}$ the functioning of this database is inadequate for third-party patent monitoring. Currently it is extremely difficult for third parties to identify all patents related to specific health technologies, as patent applicants are not required to put the name of the relevant health technology in the patent application name or summary. Companies commonly avoid doing this to create ambiguity in patent

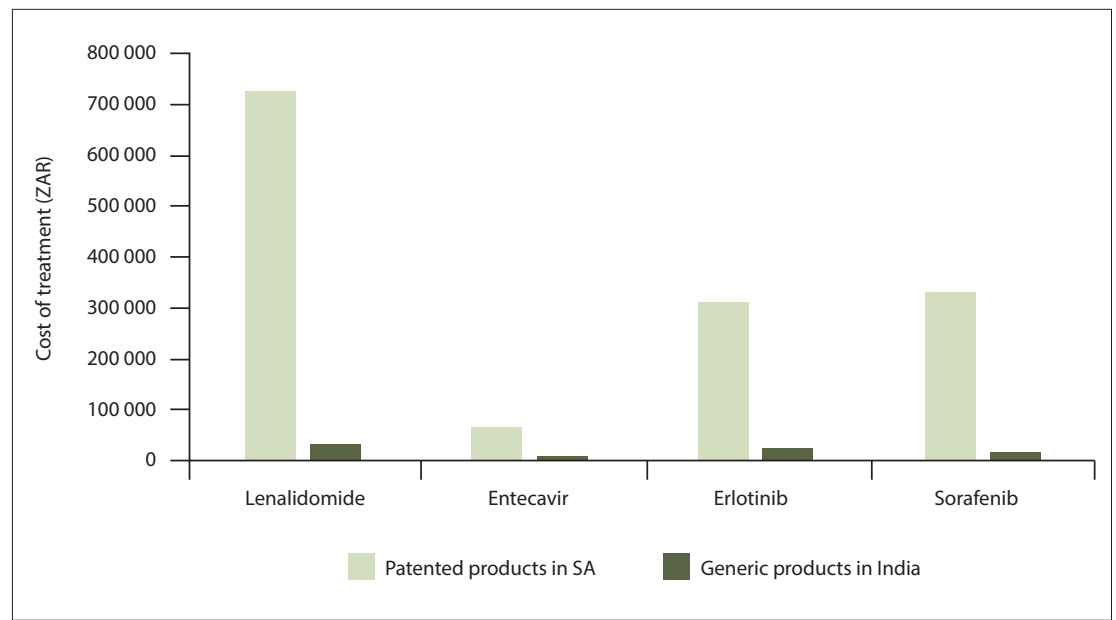

Fig. 1. Average annual cost of treatment with patented products in SA v. generic products in India. (SA = South Africa. $)$

applications and hide data on pending and granted patents. Government should require that companies disclose the international non-proprietary names (INNs) of relevant medicines in patent application titles. In cases where the INN has not yet been established, governments can require that companies retroactively provide these names.

A further complexity of undertaking patent landscapes is challenges in establishing whether or not patents related to health technologies are in fact blocking. In some cases this can only be established after a generic company seeks to launch its product at risk or legally challenge a related patent in court: the court will then establish whether the patent is blocking. To facilitate third parties (including patient groups, competitors and purchasers) in assessing whether or not patents are blocking, government should include requirements for meaningful titles on patent applications, publish clear patentability criteria, and provide full patent applications on an online searchable database (currently only a cover page and summary of the application is available). Government should also require that companies provide the outcomes of matching applications in other jurisdictions and make these data publicly available.

Greater transparency of patent data is necessary to facilitate patent oppositions by third parties. It also creates a clearer link between patients, medicines and patents, which is necessary to informing the creation of policy and legislation that upholds the constitutional rights of people living in SA.

Declaration. None.

Acknowledgements. The authors acknowledge useful comments and inputs provided on this article by Yousuf Vawda, Gaelle Krikorian and Leena Menghaney. Any errors in the article are the responsibility of the authors alone.

Author contributions. All authors contributed to the research and/or drafting of the 2016 and 2017 reports published by Fix the Patent Laws, Doctors Without Borders and Cancer Alliance on which this article is based. CT was the principal author of both research reports and this article.

Funding. None.

Conflicts of interest. None.

1. World Trade Organization. Doha Declaration on the TRIPS Agreement and Public Health. Doha: WTO, 2001. https://www. wto.org/english/thewto_e/minist_e/min01_e/mindecl_trips_e. htm (accessed 11 February 2017).

2. World Health Organization. Report of the Commission on Intellectual Property Rights, Innovation and Public Health. Geneva: WHO, 2006. http://apps.who.int/medicinedocs/ documents/s14146e/s14146e.pdf (accessed 18 April 2018).

3. United Nations. Report of the United Nations High-Level Panel on Access to Medicines: Promoting Innovation and Access to Health Access to Medicines: Promoting Innovation and Access to Health
Technologies. Geneva: UN, 2016. http://www.unsgaccessmeds. Technologies. Geneva: UN, 2016. http://www.
org/final-report/ (accessed 15 November 2016).

org/final-report/ (accessed 15 November 2016).
Kumar Jena D, Balaram P. Trends and prospects for India as Kumar Jena D, Balaram P. Trends and prospects for India as
a global generic player. In: Löfgren $\mathrm{H}$, ed. The Politics of the Pharmaceutical Industry and Access to Medicines. Melbourne: Routledge, 2017:198-225.

5. European Commission. Pharmaceutical Sector Inquiry: Final Report. EU, 2009. http://ec.europa.eu/competition/sectors/ pharmaceuticals/inquiry/staff_working_paper_part1.pdf (accessed 8 October 2015)

6. Hemphill S, Sampat B. Drug patents at the Supreme Court. Science 2013;339(6126):1386-1387. https://doi.org/10.1126/science. 1235857

7. Correa C. Pharmaceutical Innovation, Incremental Patenting and Compulsory Licensing. Geneva: South Centre, 2011. http:// apps.who.int/medicinedocs/documents/s21395en/s21395en.pdf apps.who.int/medicine
(accessed 9 May 2015).

(accessed 9 May 2015).
Velásquez G. Guidelines on Patentability and Access to Medicines: Research Paper 61. Geneva: South Centre, 2015. http://apps.who. int/medicinedocs/documents/s21801en/s21801en.pdf (accessed 30 October 2017)

9. India. Patents Act 39 of 1970. http://www.ipindia.nic.in/ writereaddata/Portal/IPOAct/1_31_1_patent-act-197011march2015.pdf (accessed 11 November 2017).

10. Argentina. Joint Resolution 118/2012, 546/2012 and 107/2012. https://wipolex.wipo.int/en/legislation/details/13007 (accessed 17 April 2018).

11. Department of Trade and Industry, South Africa. Intellectual Property Policy of the Republic of South Africa: Phase 1. DTI, 2018. http://wwwthedti.gov.za/news2018/IP_Policy2018-Phase_I, pdf (accessed 31 May 2018).

12. Tomlinson C, Ashmore J, Yawa, Hill J. Reforming South Africa’s procedures for granting patents to improve medicine access. S Afr Med J 2015;105(9):741-743. https://doi.org/10.7196/ SAMInew.8270 
13. Sampat B, Shadlen K. The Effects of Restrictions on Secondary Pharmaceutical Patents: Brazil and India in Comparative Perspective. Cambridge: Harvard, 2016. http://www.hbs.edu/faculty/Lists/Events/ Attachments/1124/Secondary\%20Pharma.pdf (accessed 2 May 2019).

14. USA. Public Law 112-29. Leahy-Smith America Invents Act. https://www.uspto.gov/sites/default/files/ USA. Public Law 112-29. Leahy-Smith America Invents Act. https://www.usp.
aia_implementation/20110916-pub-1112-29.pdf (accessed 15 September 2018).

15. Argentina. Law on Patents and Utility Models (Consolidated Text of Law No. 24.481 of 30 March 1995, Argentina. Law on Patents and Utility Models (Consolidated Text of Law No. 24.481 of 30 March 1995,
approved by Decree No. 260/1996, as amended by Law No. 24.572/1995 and Law No. 25.859/2003), approved by Decree No. 260/1996, as amended by Law No. 24.572/1995 and Law No. $25.85 /$.
Section 28. https://wipolex.wipo.int/en/legislation/details/9565 (accessed 15 September 2018).

16. Republic of Korea. Patent Act, Article 132. http://www.wipo.int/export/sites/www/scp/en/meetings/ session_25/comments_received/Republic_of_Korea_1.pdf (accessed 10 January 2018).

17. European Patents Office. Guidelines for Examination, Section 5. Grounds for Opposition. https://www. epo.org/law-practice/legal-texts/html/guidelines/e/d_iii_5.htm (accessed 10 January 2018).

18. Fix the Patent Laws. Submission on the Draft Intellectual Property Policy of the Republic of South Africa 2017. South Africa: FTPL, 2017. http://www.fixthepatentlaws.org/?p=1179 (accessed 24 October 2017)

19. Park C, Prabhala A, Berger J. Using Law to Accelerate Treatment Access in South Africa: An Analysis of Patent, Competition and Medicines Law. New York: United Nations Development Programme, 2013. https://www.undp.org/content/dam/undp/library/hivaids/English/using_law_to_accelerate_treatment_ access_in_south_africa_undp_2013.pdf (accessed 15 October 2018).

20. Fix the Patent Laws. Patent Barriers to Medicine Access in South Africa: A Case for Patent Law Reform. South Africa: FTPL, 2016. http://www.fixthepatentlaws.org/wp-content/uploads/2016/09/MSF-FTPLreport-FINAL-VERSION.pdf (accessed 2 February 2017).

21. Cancer Alliance, Fix the Patent Laws. Exploring Patent Barriers to Cancer Treatment Access in South Africa. South Africa: CA, 2017. https://www.canceralliance.co.za/important-new-report-on-patentbarriers-to-cancer-treatment-in-sa-released/ (accessed 30 October 2017).

22. Gray A, Vawda Y, Jack C. South African Health Review 2012/2013: Health Policy and Legislation. Durban: Health Systems Trust, 2013. http://www.hst.org.za/publications/South\%20African\%20 Durban: Health Systems Trust, 2013. http:/ www.hst.org.za/publicat)

23. Aventis Pharma SA and Others v Cipla Life Sciences and Others (with the Treatment Action Campaign (TAC)). 2012: ZASCA 108. http://www.saflii.org/za/cases/ZASCA/2012/108.html (accessed 15 October 2018). 2012: ZASCA 108. htp.//www.salli.org/Za/cases/ZASCA/2012/108.html (accessed 15 October 2018).

24. Bayer Pharma AG v Pharma Dynamics Ltd. 2014: ZASCA 201. http://www.saflii.org/za/cases/ ZASCA/2014/201.html (accessed 15 November 2018)

25. World Trade Organization. Agreement on Trade-Related Aspects of Intellectual Property Rights. Article 31 and 31bis. WTO, 1994. https://www.wto.org/english/docs_e/legal_e/27-trips.pdf (accessed 15 January 2019).

26. United Nations Development Programme. Using Law to Accelerate Treatment Access in South Africa. UNDP, 2013. http://www.undp.org/content/undp/en/home/librarypage/hiv-aids/using-law-toaccelerate-treatment-access-in-south-africa.html (accessed 15 November 2016).

27. Beall R, Kuhn R. Trends in compulsory licensing of pharmaceuticals since the Doha Declaration: A database analysis. PLoS Med 2012;9(1):e1001154. https://doi.org/10.1371/journal.pmed.1001154

28. Stirner B. Learning from practice: Compulsory licensing cases and access to medicines. Pharm Pat Anal 2013;2(2):195-213. https://doi.org/10.4155/ppa.12.91
29. Tomlinson C, Qiong Hu Y, Hill J, Waterhouse C. Patent Barriers to Medicine Access in South Africa: A Case for Patent Law Reform. South Africa: Fix the Patent Laws, 2016. https://www.fixthepatentlaws. A Case for Patent Law Reform. South Africa: Fix the Patent Laws, 2016. https://www.fixthepatentlaws.
org/wp-content/uploads/2016/09/MSF-FTPL-report-FINAL-VERSION.pdf (accessed 22 January 2019). 30. Tomlinson C, Moyo H, Rizvi Z, Waterhouse C, Meyer S, Low M. Exploring patent barriers to cancer Treatment access in South Africa: 24 medicine case studies. South Africa: Cancer Alliance, 2018. https://
treation treatment access in South Africa: 24 medicine case studies. South Africa: Cancer Alliance, 2018. https:/
www.canceralliance.co.za/important-new-report-on-patent-barriers-to-cancer-treatment-in-sawww.canceralliance.co.za/importa
released/ (accessed 20 January 2019).

31. SpicyIP. The Entecavir mystery: Natco and BMS enter into a hush hush patent settlement in India. 2015 https://spicyip.com/2015/01/the-entecavir-mystery-natco-and-bms-enter-into-a-hush-hush-patentsettlement-in-india.html (accessed 22 November 2018).

32. South African Medicines Formulary. 12th ed. Cape Town: Division of Clinical Pharmacology, University of Cape Town, and Health and Medical Publishing Group, 2016.

33. Khurana M. Cipla won the landmark Roche v Cipla litigation. India: IIPRD, 2012. https://iiprd.wordpress. com/tag/tarceva/ (accessed 20 October 2017)

34. Press Trust of India. Cancer drug: SC allows Cipla to withdraw appeal against Roche. India: PTI, 2014. http://www.ptinews.com/news/8802516_Cancer-drug--SC-allows-Cipla-to-withdraw-appeal-againstRoche.html (accessed 30 October 2017).

35. FiercePharma. Glenmark and Roche Settle Tarceva Patent Dispute. India: Fierce Pharma, 2016. http:/ www.fiercepharma.com/regulatory/glenmark-and-roche-settle-tarceva-patent-dispute (accessed 17 July 2017)

36. Patentscope. 1020137029130. EP2694070: Combinations of AKT inhibitor compounds and erlotinib and methods of use. https://patentscope.wipo.int/search/en/detail.js?docId=WO2012135753 (accessed 4 February 2019).

37. Patentscope. 228641. EP2694070: Combinations of AKT inhibitor compounds and erlotinib and methods of use. https://patentscope.wipo.int/search/en/detail.jsf?docId=WO2012135753 (accessed 18 Januar 2019)

38. European Patent Register. EP2694070: Combinations of AKT inhibitor compounds and erlotinib and methods of use. https://register.epo.org/application?number=EP12763771 (accessed 18 January 2019).

39. Doctors Without Borders. Bayer attempting to block affordable patented drugs in India. India: MSF, 2012 http://www.doctorswithoutborders.org/news-stories/press-release/bayer-attempting-block-affordablepatented-drugs-india (accessed 15 May 2017).

40. World Health Organization. Bridging the Gap in South Africa. Geneva: WHO, 2010. http://www.who. int/bulletin/volumes/88/11/10-021110/en/ (accessed 25 August 2017)

41. Companies and Intellectual Property Commission. Online Patent Register. https://patentsearch.cipc. co.za/patents/patentsearch.aspx (accessed 22 January 2018).

Accepted 14 March 2019 